\title{
Relationship between Glucagon-Induced Cyclic AMP Accumulation and DNA Synthesis in Carbon Tetrachloride-Intoxicated Rat Liver
}

\author{
Shinichi HATTA \\ Department of Pharmacology. Sapporo Medical College, \\ South 1. West 17. Sapporo 060, Japan \\ Accepted July 14, 1984
}

It has been suggested that hepatocyte proliferation is controlled by humoral factors (1). Glucagon, in particular, has been said to be involved in the proliferation of liver cells in experiments using intact livers (2). regenerating livers after partial hepatectomy (3), and cultured liver cells (4). The growthpromoting effect of glucagon may be mediated via cyclic AMP since cyclic AMP can effectively mimic glucagon in the stimulation of hepatic DNA synthesis $(4,5)$. On the other hand, little work has been done to study the effect of glucagon on the regeneration of hepatocytes following liver injury $(6,7)$, and the role of glucagon in the regeneration of injured liver is not well defined.

The present study was undertaken to examine whether or not glucagon is involved in the regeneration of injured liver. The effect of glucagon on hepatic DNA synthesis and the relationship of glucagon-induced hepatic accumulation of cyclic AMP to the glucagon effect on DNA synthesis were studied in carbon tetrachloride $\left(\mathrm{CCl}_{4}\right)$-intoxicated rats.

Male Wistar rats (weighing 260-320 g) were used for the experiments. $\mathrm{CCl}_{4}(1 \mathrm{ml} /$ $\mathrm{kg}$, b.w.) in $50 \%$ olive oil solution was administered by a stomach tube and normal control rats received olive oil alone. To determine hepatic DNA synthesis, rats were injected intraperitoneally with $5 \mu \mathrm{Ci}$ (methyl${ }^{3} \mathrm{H}$ ) thymidine $(25 \mathrm{Ci} / \mathrm{mmol}$. Amersham) per $100 \mathrm{~g}$ body weight and killed $1 \mathrm{hr}$ later. A portion of the liver $(1 \mathrm{~g})$ was homogenized in 19 volumes of cold distilled water. DNA was extracted from the homogenate as described by Munro and Fleck (8), and the amount of radioactivity incorporated into DNA was determined by counting on a Beckman LS 9000 scintillation spectrometer.
DNA was measured by the method of Martin et al. (9) using calf thymus DNA standards. ${ }^{3} \mathrm{H}$-Thymidine incorporated into liver DNA was expressed as cpm/mg DNA. Because the peak of stimulated DNA synthesis was found $24 \mathrm{hr}$ after the injection of the hormone in preliminary experiments, glucagon (500 $1 / \mathrm{g} / \mathrm{kg}$ ) (Sigma Chemical Co.. St. Louis) or saline (as control) was injected subcutaneously $24 \mathrm{hr}$ before the estimation of DNA synthesis.

To examine the effect of glucagon on liver cyclic AMP, the hepatic level of cyclic AMP was determined. Under pentobarbital anesthesia, rats were subcutaneously injected with glucagon $(500 \mu \mathrm{g} / \mathrm{kg})$ or saline. Fifteen min after the injection, a portion of the liver was excised and rapidly frozen in a liquid nitrogen-cooled clamp. Tissue content of the cyclic AMP was measured by radioimmunoassay (10) using a commercial assay kit (Yamasa, Choshi, Japan). The adenylate cyclase response to glucagon was also determined in normal and $\mathrm{CCl}_{4}$-treated rats. A portion of the liver was homogenized with ice-cold $25 \mathrm{mM}$ Tris buffer, $\mathrm{pH} 7.6$, containing $5 \mathrm{mM} \mathrm{MgCl}_{2}$ and $1 \mathrm{mM}$ dithiothreitol. The homogenate was filtered through four layers of cheesecloth and centrifuged at $900 \times \mathrm{g}$ for $5 \mathrm{~min}$. The sediment was washed three times and resuspended in the same homogenization medium. The $900 \times \mathrm{g}$ particulate fractions were stored at $-80^{\circ} \mathrm{C}$ until the analysis of the adenylate cyclase. The adenylate cyclase activity was measured using ( $\alpha$ - $\left.{ }^{32} \mathrm{P}\right)$ ATP (45 Ci/mmol, Amersham) according to the method of Salomon et al. (11) in the presence of $10 \mathrm{mM}$ theophylline. Incubation was performed for $10 \mathrm{~min}$ at $30^{\circ} \mathrm{C}$. The reaction was stopped with a solution of $2 \%$ sodium dodecyl sulfate, 40 
$\mathrm{mM}$ ATP and $1.4 \mathrm{mM}$ cyclic AMP. The sample was counted on a Beckman LS 9000 scintillation spectrometer. Protein was determined by the method of Lowry et al. (12). Results are given as the mean \pm S.E. Student's t-test was used for calculating statistical significance.

The effects of glucagon on hepatic DNA synthesis in normal and $\mathrm{CCl}_{4}$-treated rats are shown in Table 1. Basal DNA synthesis (without glucagon) was elevated 48 and $72 \mathrm{hr}$ following $\mathrm{CCl}_{4}$ intoxication, indicating liver regeneration after the intoxication (13). and the peak of basal DNA synthesis was observed at $48 \mathrm{hr}$. Hepatic DNA synthesis in normal rats was increased by glucagon to 2 -fold that of basal DNA synthesis. This result is compatible with a previous report (2). Furthermore, $48 \mathrm{hr}$ after $\mathrm{CCl}_{4}$ intoxication in rats, glucagon strikingly stimulated hepatic DNA synthesis to 4.8 -fold that of basal DNA synthesis. This stimulatory effect of glucagon was also observed $72 \mathrm{hr}$ after the intoxication. Thus, glucagon effectively stimulated DNA synthesis in rats after $\mathrm{CCl}_{4}$ intoxication and marked stimulation of DNA synthesis by glucagon was observed coincidently in time with the peak of elevation in basal DNA synthesis. These results indicate that glucagon plays a positive role in regulating liver regeneration after $\mathrm{CCl}_{4}$ intoxication.

To examine the possible relationship between the effects of glucagon observed in Table 1 and the ability of glucagon to stimulate hepatic accumulation of cyclic AMP, the effects of glucagon in increasing the hepatic levels of cyclic AMP were studied in normal and $\mathrm{CCl}_{4}$-treated rats. These results are shown in Table 2 . Glucagon caused a remarkable increase of cyclic AMP in the livers of normal rats. On the other hand, hepatic accumulation of cyclic AMP by glucagon was significantly decreased both

Table 1. Effects of glucagon on hepatic DNA synthesis

\begin{tabular}{ccc}
\hline $\begin{array}{c}\text { Time after } \mathrm{CCl}_{4} \\
\text { administration } \\
(\mathrm{hr})\end{array}$ & DNA synthesis (cpm/mg DNA) \\
0 & Saline & G!ucagon \\
24 & $2252 \pm 115(9)$ & $4459 \pm 451(5)^{\prime \prime}$ \\
48 & $2681 \pm 404(3)$ & \\
72 & $5127 \pm 563(8)^{\prime \prime}$ & $20724 \pm 4339(4)^{\prime \prime}$ \\
\hline
\end{tabular}

The results are given as the mean \pm S.E. The number of observations is shown in parentheses. Glucagon $(500 \mu \mathrm{g} / \mathrm{kg})$ or saline was injected $24 \mathrm{hr}$ before the estimation of DNA synthesis. :P $<0.05$ compared with the saline-injected control in normal rats. " $\mathrm{P}<0.05$. $\mathrm{P}<0.001$ compared with the corresponding saline-injected control.

Table 2. Effects of glucagon on hepatic levels of cyclic AMP and adenylate cyclase activity in the $900 \times \mathrm{g}$ particulate fractions

Time after $\mathrm{CCl}_{4}$ administration (hr)

$\begin{array}{rcr} & \text { Salirie } \\ 0 & 0.80 \pm 0.07 & (5) \\ 24 & 0.84 \pm 0.04 & (4) \\ 48 & 1.03 \pm 0.09 & (8)\end{array}$

cyclic AMP level

(nmol/g tissue)
Glucagon $(500 \mu \mathrm{g} / \mathrm{kg}$ )
Adenylate cyclase activity (pmol cyclic AMP/mg protein/10 min)

$\begin{array}{lll}9.13 \pm 0.83(3) & 45.4 \pm 8.3 \\ 2.53 \pm 0.54(3): 1 & 42.1 \pm 7.5 \\ 4.22 \pm 0.33(3): 1 & 77.7 \pm 11.8\end{array}$

Glucagon
$\left(10^{-6} \mathrm{M}\right)$

$477.0 \pm 60.7$

$283.2 \pm 52.6^{\prime \prime}$

$336.8 \pm 61.1$
$\mathrm{NaF}$ $\left(10^{-2} \mathrm{M}\right)$

$342.4 \pm 32.3$

$331.1 \pm 29.4$

$375.5 \pm 82.1$

The results are given as the mean \pm S.E. The number of observations for hepatic cyclic AMP levels is shown in parentheses. The results of adenylate cyclase activity were obtained from 4 or 5 experiments in duplicate assay. "P<0.01 compared with the glucagon-induced accumulation of cyclic AMP in normal rats. ${ }^{\mathrm{b}} \mathrm{P}<0.05$ compared with the glucagon-stimulated activity in normal rats. 
at $24 \mathrm{hr}$ after the intoxication (to $28 \%$ of the glucagon-induced accumulation in normal rats) and at $48 \mathrm{hr}$ (to $46 \%$ ). Furthermore. consistent with the decline in the glucagoninduced hepatic accumulation of cyclic AMP. glucagon-stimulated activity of adenylate cyclase was found to be decreased in the $900 \times g$ particulate fractions obtained from rats 24 and $48 \mathrm{hr}$ after the intoxication when compared with such activity in the particulate fractions obtained from normal rats (Table 2). In contrast, when normal and $\mathrm{CCl}_{4}$-treated rats were compared, there was no appreciable alteration in fluoride-stimulated activity. A reduction in the adenylate cyclase response to glucagon in $\mathrm{CCl}_{4}$-treated rats has been reported by Mourelle and Rubalcava (14). Since no essential difference in fluoridestimulated activity of adenylate cyclase was observed between normal and $\mathrm{CCl}_{4}$-treated rats (Table 2), the attenuation in the cyclic AMP response to glucagon observed in $\mathrm{CCl}_{4}$-treated rats might partially result from a decrease in the number of glucagon receptors (14).

It has been suggested that the growthpromoting effect of glucagon is mediated by cyclic AMP. However, the potentiating effect of glucagon on hepatic DNA synthesis observed in $\mathrm{CCl}_{4}$-treated rats could not be ascribed to the glucagon-induced hepatic accumulation of cyclic AMP. The apparent absence of any relationship between the effects of glucagon on cyclic AMP and DNA synthesis may suggest that additional factors other than cyclic AMP are also involved in the induction of hepatic DNA synthesis by glucagon. Laks et al. (15) recently reported that additional factors other than cyclic AMP are required for the increase of cyclic AMP-dependent protein kinase. which may be involved in the initiation of DNA synthesis (16), in the nucleus in the regenerating liver after partial hepatectomy. It may be possible that deficient states of insulin and iodothyronine, which occur before the initiation of DNA synthesis in $\mathrm{CCl}_{4}$-treated rats (14, $17)$ and in partially hepatectomized rats (18). are responsible for the potentiating effect of glucagon on DNA synthesis. However, neither insulin deficiency nor iodothyronine deficiency, alone, brings about the potentia- tion of the glucagon effect on DNA synthesis (17). Other interpretations may be possible and further investigations are needed to clarify the situation.

Although the mechanism of the potentiating effect of glucagon on hepatic DNA synthesis in $\mathrm{CCl}_{4}$-treated rats is not clear, the present study suggests that glucagon participates in liver regeneration after $\mathrm{CCl}_{4}$ intoxication.

Acknowledgments: I am grateful to Drs. M. Tanaka and $\mathrm{H}$. Ohshika for valuable advice on this study. This work was supported in part by a Research Grant from the Kuribayashi Foundation.

\section{References}

1 Fisher, B.. Szuch, P., Levine, M. and Fisher, E.R.: A portal blood factor as the humoral agent in liver regeneration. Science 171,575-577 (1971)

2 Hasegawa, K. and Koga, M.: Induction of liver cell proliferation in intact rats by amines and glucagon. Life Sci. 21, 1723-1728 (1977)

3 Bucher, N.L.R. and Swaffield, M.N.: Regulation of hepatic regeneration in rats by synergistic action of insulin and glucagon. Proc. Natl. Acad. Sci. U.S.A. 72, 1157-1160 (1975)

4 Armato, U., Draghi, E. and Andreis, P.G.: Effect of glucagon and insulin on the growth of neonatal rat hepatocytes in primary tissue culture. Endocrinology 102, 1155-1166 (1978)

5 Hasegawa, K., Namai, K. and Koga, M.: Induction of DNA synthesis in adult rat hepatocytes cultured in a serum-free medium. Biochem. Biophys. Res. Commun. 95, 243-249 (1980)

6 Farivar, M., Wands, J.R., Isselbacher, K.J. and Bucher, N.L.R.: Effect of insulin and glucagon on fulminant murine hepatitis. N. Engl. J. Med. 295 , 1517-1519 (1976)

7 Nozawa, K.: Effects of glucagon, insulin and glucocorticoid on experimental liver injuries and liver regeneration. Shinshu Med. J. 30, 621-633 (1982) (Abs. in English)

8 Munro, H.N. and Fleck, A.: The determination of nucleic acids. Methods Biochem. Anal. 14, 113176 (1966)

9 Martin, R.F., Donohue, D.C. and Finch, L.R.: New analytical procedure for the estimation of DNA with p-nitrophenylhydrazine. Anal. Biochem. 47, 562-574 (1972)

10 Honma, M., Satoh, T., Takezawa, J. and Ui, M.: An ultrasensitive method for the simultaneous determination of cyclic AMP and cyclic GMP in small-volume samples from blood and tissue. Biochem. Med. 18, 257-273 (1977) 
11 Salomon, Y., Londos, C. and Rodbell, M.: A highly sensitive adenylate cyclase assay. Anal. Biochem. 58, 541-548 (1974)

12 Lowry, O.H., Rosebrough. N.J., Farr, A.L. and Randall, R.J.: Protein measurement with the Folin phenol reagent. J. Biol. Chem. 193, 265275 (1951)

13 Leevy, C.M., Hollister, R.M., Schmid, R., MacDonald, R.A. and Davidson, C.S.: Liver regeneration in experimental carbon tetrachloride intoxication. Proc. Soc. Exp. Biol. Med. 102, 672-675 (1959)

14 Mourelle, M. and Rubalcava, B.: Regeneration of the liver after carbon tetrachloride. Differences in adenylate cyclase and pancreatic hormone receptors. J. Biol. Chem. 256, 1656-1660 (1981)

15 Laks, M.S., Harrison, J.J., Schwock, G. and Jungmann, R.A.: Modulation of riuclear protein kınase activity and phosphorylation of histone $\mathrm{H} 1$ subspecies during the prereplicative phase of rat liver regeneration. J. Biol. Chem. 256, 87758785 (1981)

16 Boynton, A.L., Whitfield, J.F., MacManus, J.P., Armato, U., Tsang, B.K. and Jones, A.: Involvement of CAMP and CAMP-dependent protein kinase in the initiation of DNA synthesis by rat liver cells. Exp. Cell Res. 135, 199-211 (1981)

17 Hatta, S., Ohshika, H. and Tanaka, M.: Hepatic response in DNA synthesis to adrenergic agonists, insulin and glucagon in $\mathrm{CCl}_{4}$-treated rats. Japan. J. Pharmacol. 33, Supp. 186P (1983)

18 Leffert, H., Alexander, N.M., Faloona, G., Rubalcava, B. and Unger, R.: Specific endocrine and hormorial receptor changes associated with liver regeneration in adult rats. Proc. Natl. Acad. Sci. U.S.A. 72, 4033-4036 (1975) 